\title{
Activation of Phospholipase C in Human B Cells Is Dependent on Tyrosine Phosphorylation
}

\author{
Shai Padeh,* Alexander Levitzki, ${ }^{*}$ Aviv Gazit, ${ }^{*}$ Gordon B. Mills, ${ }^{5}$ and Chaim M. Roifman* \\ *Division of Immunology/Allergy, Department of Pediatrics, The Hospital for Sick Children, Toronto, Ontario, M5G 1 X8; \\ ${ }^{\ddagger}$ The Department of Biological Chemistry, Hebrew University of Jerusalem, Jerusalem 91904, Israel; \\ and ${ }^{8}$ Oncology Research, Toronto General Hospital, Toronto, Ontario, M5G 2 C4
}

\begin{abstract}
Cross-linking of the surface antigen receptor on $B$ lymphocytes has been demonstrated to lead to activation of phospholipase $C$ (PLC) with subsequent increases in production of inositol phosphates and diacylglycerol. In turn, these second messengers increase cytosolic free calcium $\left(\left[\mathrm{Ca}^{2+}\right]_{1}\right)$ and activate the serine threonine phosphotransferase protein kinase $\mathrm{C}$ (PKC). These processes are thought to play a major role in $B$ cell activation and proliferation. However, the mechanism linking the $B$ lymphocyte antigen receptor to phospholipase $C$ remains to be identified. We demonstrate herein that activation of the antigen receptor on human lymphocytes, in addition to activation of PLC, increases tyrosine phosphorylation of specific substrates. Tyrphostins, a new class of tyrosine kinase inhibitors which compete for substrate binding site of specific tyrosine kinases have recently been synthesized. Preincubation of B lymphocytes with two different tyrphostins blocked anti-IgM-induced proliferation, oncogene expression, tyrosine phosphorylation, increases in $\left[\mathrm{Ca}^{2+}\right]_{1}$, and production of inositol phosphates. The same inhibitors were without effect on B cell proliferation induced by phorbol esters and cation ionophores which directly activate PKC and increase $\left[\mathrm{Ca}^{2+}\right]_{i}$ thus bypassing PLC. These findings strongly indicate that tyrphostins do not exhibit signifcant nonspecific toxicity and suggest that they act proximal to PLC. The ability of the tyrphostins to block increases in $\left[\mathrm{Ca}^{2+} \mathrm{h}_{\mathrm{H}}\right.$ and inositol phosphate production, after activation of the $B$ cell antigen receptor, indicates that a tyrosine kinase acts as an essential link between the B cell antigen receptor and PLC. (J. Clin. Invest. 1991. 87:1114-1118.) Key words: inositol-trisphosphate $\left(\mathrm{IP}_{3}\right) \cdot$ protein kinase $\mathrm{C}(\mathrm{PKC}) \cdot$ phospholipase $\mathrm{C}$ (PLC) • protein tyrosine kinase (PTK) ・ 12-0-tetradecanoylphorbol 13-acetate (TPA)
\end{abstract}

Address correspondence and reprint requests to Chaim M. Roifman, Division of Immunology/Allergy, The Hospital for Sick Children, 555 University Avenue, Toronto, Ontario, M5G 1X8, Canada.

Received for publication 11 October 1990 and in revised form 29 November 1990.

1. Abbreviations used in this paper: $\left[\mathrm{Ca}^{2+}\right]_{\mathrm{i}}$, cytosolic free calcium; IP, inositol phosphate; PLC, phospholipase C; TPA, tetradecanoylphorbol acetate.

J. Clin. Invest.

(c) The American Society for Clinical Investigation, Inc.

0021-9738/91/03/1114/05 \$2.00

Volume 87, March 1991, 1114-1118

\section{Introduction}

Cross-linking the antigen receptor on B cells with anti-Ig antibody mimics the effect of antigen (1-3). Activation of the B cell antigen receptor leads to phospholipase $C(P L C)^{1}$-mediated breakdown of membrane phosphatidylinositols which produces two intracellular second messengers, namely inositol trisphosphate $\left(\mathrm{IP}_{3}\right)$ and diacylglycerol $(\mathrm{DAG})(4,5)$. In turn, $\mathrm{IP}_{3}$ increases cytosolic free calcium $\left(\left[\mathrm{Ca}^{2+}\right]_{i}\right)$, while DAG is a physiologic activator of the serine threonine-specific phosphotransferase, protein kinase $C$. This bifurcating pathway is considered to initiate the cascade of biochemical events leading to $B$ cell activation as well as clonal expansion $(4,5)$. Consistent with recent reports, we have shown that triggering the antigen receptor on B cells results in a rapid increase in tyrosine phosphorylation of a number of proteins (6-9). Activation of PLC and resultant increases in $\left[\mathrm{Ca}^{2+}\right]_{\mathrm{i}}$ induced by the epidermal growth factor, platelet derived growth factor, and $\mathrm{T}$ cell receptors is dependent on tyrosine kinase activity of the receptors $(10,11)$. To test whether activation of PLC was similarly dependent on tyrosine phosphorylation in B cells, we determined the effect of a series of specific tyrosine kinase inhibitors, designated tyrphostins, on anti-IgM-induced increases in PLC activity. Tyrphostins, in contrast to genestein (12), quercetin (13), and herbimycin, which compete for the ATP binding site and thus may interfere with other kinases and other ATP-dependent processes, compete for the substrate binding sites of tyrosine kinases (14-16). The marked structural differences between tyrosine and serine or threonine leads to a marked specificity for tyrosine kinases.

Using specific tyrphostins, we demonstrate that PLC activation, cell proliferation, oncogene expression, and tyrosine phosphorylation are blocked in parallel. This suggests that a tyrosine kinase acts as an intermediary between the B cell antigen receptor and phospholipase $\mathrm{C}$.

\section{Methods}

Cell preparation. Tonsil tissue was obtained from patients undergoing tonsillectomy. Mononuclear cells were isolated by Ficoll-Hypaque density gradient centrifugation. $T$ cell depletion was accomplished by removing, by Ficoll-Hypaque centrifugation, the cells that rosetted with 2-aminoethyl-isothiouronium bromide-treated sheep erythrocytes. Adherent cells were removed by adherence to plastic dishes for $60 \mathrm{~min}$ at $37^{\circ} \mathrm{C}$. The resulting $\mathrm{B}$ cell-enriched population was $<55 \%$ $\mathrm{OKT}_{1} 1^{+}(\mathrm{CD} 2, \mathrm{~T}$ cell marker $)$ and $>95 \% \mathrm{Bl}^{+}(\mathrm{B}$ cell marker $)$ as measured by immunofluorescence staining. Surface Ig was present on $>95 \%$ of the cells.

Reagents. Affinity purified goat antibodies directed against human IgM were purchased from Tago Inc. (Burlingame, CA). For prolifer- 
ation assays, anti-IgM was cross-linked to $\mathrm{CNBr}$ treated sepharose beads (Pharmacia Fine Chemicals, Piscataway, NJ) as previously described (17). Ionomycin and 12-O-tetradecanoylphorbol 13-acetate (TPA) were from Calbiochem-Behring Corp. (San Diego, CA). $\left.{ }^{3} \mathrm{H}\right]$ Thymidine was obtained from Amersham Corp. (Arlington Heights, IL). ${ }^{125}$ I-labeled protein A was obtained from ICN Pharmaceuticals, Inc. (Irvine, CA). Polyclonal anti-phosphotyrosine antibodies were a kind gift from Dr. T. Pawson (University of Toronto). In addition, affinity purified polyclonal anti-phosphotyrosine antibodies were purchased from Upstate Biotechnology Inc., New York. These antibodies gave identical results to those provided by Dr. T. Pawson. Plasmid DNA for $c$-fos and $\beta$-actin were obtained from the American Type Culture Collection (Rockville, MD).

Tyrphostins were derived from benzylidenemalononitrile (BMN) nucleus. These compounds resemble the moieties, tyrosine and erbstatin at the same time. The second cyano group in BMN was found to increase the biological activity as previously described (14-16). The guidelines for selection of compounds included compounds soluble in water as well as in mildly hydrophobic solvents. Such solubility properties allow the compounds to traverse the cell membrane of intact cells.

Cell proliferation. B lymphoctyes were incubated in round bottom tissue culture plates (Costar, Cambridge, MA). As indicated, $4 \mathrm{~h}$ before termination of the culture $1 \mu \mathrm{Ci}\left[{ }^{3} \mathrm{H}\right]$ thymidine $(6.7 \mathrm{Ci} / \mathrm{mmol})$ was added. The cells were then harvested and samples counted in a liquid scintillation counter.

Western blotting. Western blotting was performed essentially as described (18). B cells were stimulated as indicated, sedimented, and lysed with boiling SDS. Proteins were separated on SDS-PAGE, transferred to nitrocellulose, and blotted with the anti-ptyr antibodies. Antibody reactivity was detected with ${ }^{125}$ I-labeled protein $A$ and autoradiography.

$\left[\mathrm{Ca}^{2+}\right]_{i}$ measurement. $\left[\mathrm{Ca}^{2+}\right]_{i}$ was measured with indo-1 as previously described (5).

Phosphoinositol production. B cells were incubated overnight in inositol-free RPMI (Media Preparations Services, Toronto, Canada) supplemented with glutamine, mercaptoethanol, and $10 \%$ FCS. Cells $\left(10^{8}\right)$ were incubated in inositol-free RPMI with $100 \mu \mathrm{Ci}$ of $\left[{ }^{3} \mathrm{H}\right]$ inositol (New England Nuclear, Lachine, Quebec) for $4 \mathrm{~h}$. Cells were then incubated with $\mathrm{LiCl}(20 \mathrm{mM})$ for $15 \mathrm{~min}$ to prevent breakdown of myoinositol 1-phosphate (IP) and myoinositol 1,4-bisphosphate (IP $\left.{ }_{2}\right)$. Cells were incubated with anti-IgM antibodies as indicated. Cells were lysed as described and inositol phosphates isolated by passage over Dowex 1 $\times 8$ columns as previously reported $(5) .\left[{ }^{3} \mathrm{H}\right]$ Inositol was determined by scintillation counting.

Phosphoinositol-bisphosphate phospholipase $C$ assay. Cells were lysed by hyptonic stress, membranes, and cytosol were prepared by density gradient centrifugation. PLC was assayed in final volume of 40 $\mu$ containing $25 \mathrm{mM}$ sodium phosphate ( $\mathrm{pH} 6.7$ ), $1 \mathrm{mM}$ sodium pyrophosphate, $40 \mathrm{mM} \mathrm{Kcl}, 0.4 \mathrm{mM}$ EGTA, $0.8 \mathrm{mM} \mathrm{Cacl}_{2}, 0.5 \%$ octyglucoside, and $0.2 \mathrm{mM}\left[{ }^{3} \mathrm{H}\right]$ phosphatidylinositol-4,5-bisphosphate $(5 \mathrm{Ci} /$ mol). After incubation at $37^{\circ} \mathrm{C}$ for $10 \mathrm{~min}$ the reaction was stopped by rapid cooling on ice and by adding $5 \%$ trichloroacetic acid. The precipitate was removed and radioactivity present in $0.5 \mathrm{ml}$ of the supernatant was measured as previously described $(11,19)$.

Northern blot analysis. RNA was extracted from cells in guanidinium isothiocyanate according to the method of Chomczynski and Sacchi (20). Purified RNA (10 $\mu \mathrm{g})$ was electrophoresed, subsequently transferred to nitrocellulose, blotted, and hybridized with labeled probes as previously described (21).

\section{Results}

We used Western blotting with specific polyclonal anti-phosphotyrosine antibodies to test whether cross-linking the B cell antigen receptor with anti-IgM antibodies results in increases in tyrosine phosphorylation. These polyclonal anti-phosphotyrosine antibodies have been demonstrated to react specifically with phosphotyrosine and not with phosphoserine or phosphothreonine (18).
Incubation of B lymphocytes with anti-IgM antibodies induced a rapid increase in tyrosine phosphorylation of three major bands with molecular weights 74,93 , and $110 \mathrm{kD}$ and three minor bands with molecular weights of 46, 57, and 145 kD (Fig. 1). Tyrosine phosphorylation was detected within $30 \mathrm{~s}$ of addition of anti-IgM antibodies with maximal increases in tyrosine phosphorylation observed 3-5 min later (not presented). Previous reports have demonstrated that binding of antibody to the antigen receptor on human B cells $(6,7)$ and murine B cells $(8,9)$ was associated with increased phosphorylation of tyrosine residues. However, a direct link between this early event and proliferation of B cells has not been established. As indicated in Table I, the tyrphostins, AG-30 and AG-126, blocked $\mathrm{B}$ cell proliferation induced by anti-IgM antibodies bound to beads. AG-30 and AG-126 did not alter B cell proliferation induced by TPA and ionomycin, indicating that the inhibition of anti-IgM-induced proliferation was not due to nonspecific toxicity. In contrast, AG-183, AG-294, and AG-376, which are effective inhibitors of purified epidermal growth factor receptor tyrosine kinase activity $(14,15)$, had little effect on anti-IgM-induced proliferation at similar concentrations (Fig. 2). Remarkably, AG-30 and AG-126 are relatively ineffective inhibitors of the EGF receptor, tyrosine kinase (19; and Levitzki et al., unpublished observations).

As indicated in Fig. 1, preincubation with $50 \mu \mathrm{M}$ of AG-30 and AG-126 blocked anti-IgM-induced tyrosine phosphorylation. Note that preincubation with the tyrphostins did not decrease the phosphotyrosine levels to zero, but rather resulted in a pattern that was indistinguishable from the pattern of nonstimulated cells. At least $2 \mathrm{~h}$ of preincubation was required to

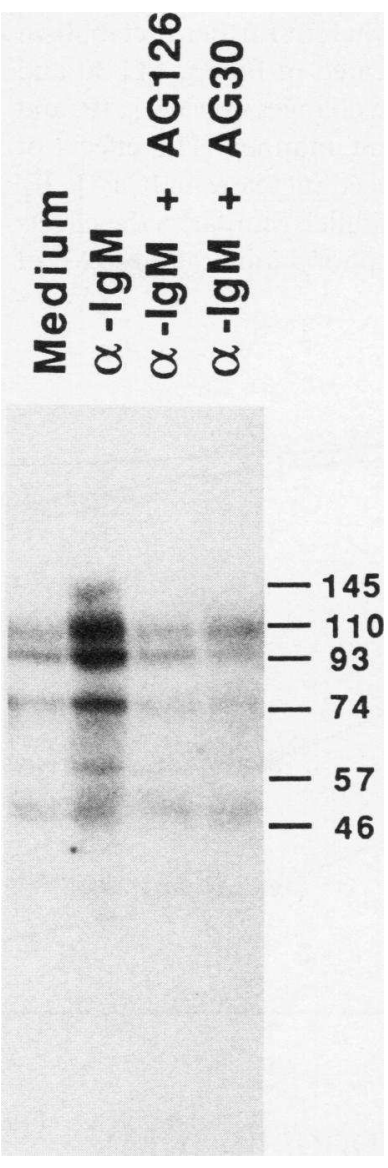

Figure 1. Effect of tyrphostins on anti-IgM antibody-induced tyrosine phosphorylation. AntiIgM antibodies $(20 \mu \mathrm{g} / \mathrm{ml})$ were added to $B$ cell cultures in the presence or absence of the tyrphostins AG-30 $(50 \mu \mathrm{M})$ and AG-126 $(50 \mu \mathrm{M})$. Cells were incubated with the tyrphostins $2 \mathrm{~h}$ before and terminated $3 \mathrm{~min}$ after the addition of anti-IgM antibodies. After electrophoresis and blotting, the phosphotyrosinecontaining proteins were detected using phosphotyrosine antibodies and ${ }^{125}$ I-labeled protein $\mathrm{A}$. The resultant autoradiogram is displayed. 


\begin{tabular}{lccc}
\hline & & \multicolumn{2}{c}{ Tyrphostins } \\
\cline { 2 - 4 } & Medium & AG-30 $(30 \mu \mathrm{M})$ & AG-126 $(30 \mu \mathrm{M})$ \\
\hline Medium & $750 \pm 105$ & $620 \pm 195$ & $480 \pm 15$ \\
Anti-IgM $(20 \mu \mathrm{g} / \mathrm{ml})$ & $1,075 \pm 240$ & $810 \pm 200$ & $595 \pm 260$ \\
Anti-IgM (bound to beads) & $16,900 \pm 1,300$ & $3,330 \pm 180$ & $1,050 \pm 75$ \\
TPA + ionomycin & $58,150 \pm 4,710$ & $55,800 \pm 5,130$ & $52,100 \pm 3,820$
\end{tabular}

Tonsil B cells $\left(2 \times 10^{6} / \mathrm{ml}\right)$ were cultured for $3 \mathrm{~d}$ with or without anti-IgM antibody $(20 \mu \mathrm{g} / \mathrm{ml})$, anti-IgM $(20 \mu \mathrm{g} / \mathrm{ml})$ bound to beads or with the combination of TPA $\left(10^{-8} \mathrm{M}\right)$ and ionomycin $(1 \mu \mathrm{g} / \mathrm{ml})$. $\left[{ }^{3} \mathrm{H}\right]$ Thymidine incorporation values represent mean \pm SD of five separate experiments.

consistently block tyrosine phosphorylation (not presented), which is similar to observations in other cell types $(14,16)$. Once again, AG-183, AG-294, and AG-376 had little effect on anti-IgM-induced tyrosine phosphorylation (not presented).

One of the earliest events following cross-linking the $\mathrm{B}$ cell antigen receptors is an increase in $\left[\mathrm{Ca}^{2+}\right]_{i}(5)$. This is believed to result, at least in part, from PLC-mediated increases in $\mathrm{IP}_{3}$ production $(4,5)$. Since increases in tyrosine phosphorylation preceded increases in $\left[\mathrm{Ca}^{2+}\right]_{i}$, but mimicking PLC activation (by treatment with TPA and ionomycin), did not increase tyrosine phosphorylation (not presented), tyrosine phosphorylation may be an upstream event required for PLC activation. We tested this possibility by blocking anti-IgM-induced increases in tyrosine phosphorylation with AG-30 and AG-126 and measured the effect on ligand-induced increases in $\left[\mathrm{Ca}^{2+}\right]_{i}$

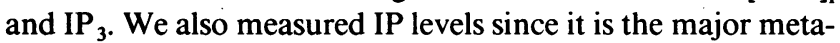
bolic product of $\mathrm{IP}_{3}$ in these cells wherein further metabolism was blocked with lithium. As indicated in Fig. 3, AG-30 and AG-126 inhibited anti-IgM-induced changes in $\left[\mathrm{Ca}^{2+}\right]_{i}, I P$, and $\mathrm{IP}_{3}$ production in a dose-dependent manner. The effects of AG-30 and AG-126 on ligand-induced increases in $\left[\mathrm{Ca}^{2+}\right]_{\mathrm{i}}$, IP, and $\mathrm{IP}_{3}$ production were roughly parallel. Similar to the effects on anti-IgM-induced tyrosine phosphorylation, at least $2 \mathrm{~h}$ of preincubation was required to consistently block anti-IgM-induced changes in $\left[\mathrm{Ca}^{2+}\right]_{i}, I P$, and $\mathrm{IP}_{3}$ production (not presented).

One of the earliest correlates of mitogenesis in a variety of cell types is the increased expression of the nuclear proto-oncogene, $c$-fos $(22,23)$. Expression of this gene increases within 5 min and reaches maximal expression $\sim 30$ min after stimulation of human B cells by mitogens (24). It has been postulated that this protein regulates the subsequent expression of other genes in the cascade which ultimately culminates in proliferation. Because of its rapid onset, $c$-fos expression was used to study the effect of AG-30 and AG-126 on anti-IgM-induced B cell activation. Northern blot analysis of total cytoplasmic RNA extracted from B cells incubated for $30 \mathrm{~min}$ with antiIgM indicated that these agents increased fos expression (Fig. 4). Consistent with our previous observations (24), TPA and ionomycin or anti-IgM induced a 7.5- and 6-fold increase in c-fos expression, respectively. Preincubation of $\mathrm{B}$ cells with AG-30 or AG-126 for $2 \mathrm{~h}$ before treatment with anti-IgM prevented the anti-IgM-induced increases in $c$-fos RNA expression (Fig. 4). In contrast, AG-30 and AG-126 did not inhibit the TPA and ionomycin-induced increase in $c$-fos RNA expression in B cells (not presented). This finding suggests that the tyr-
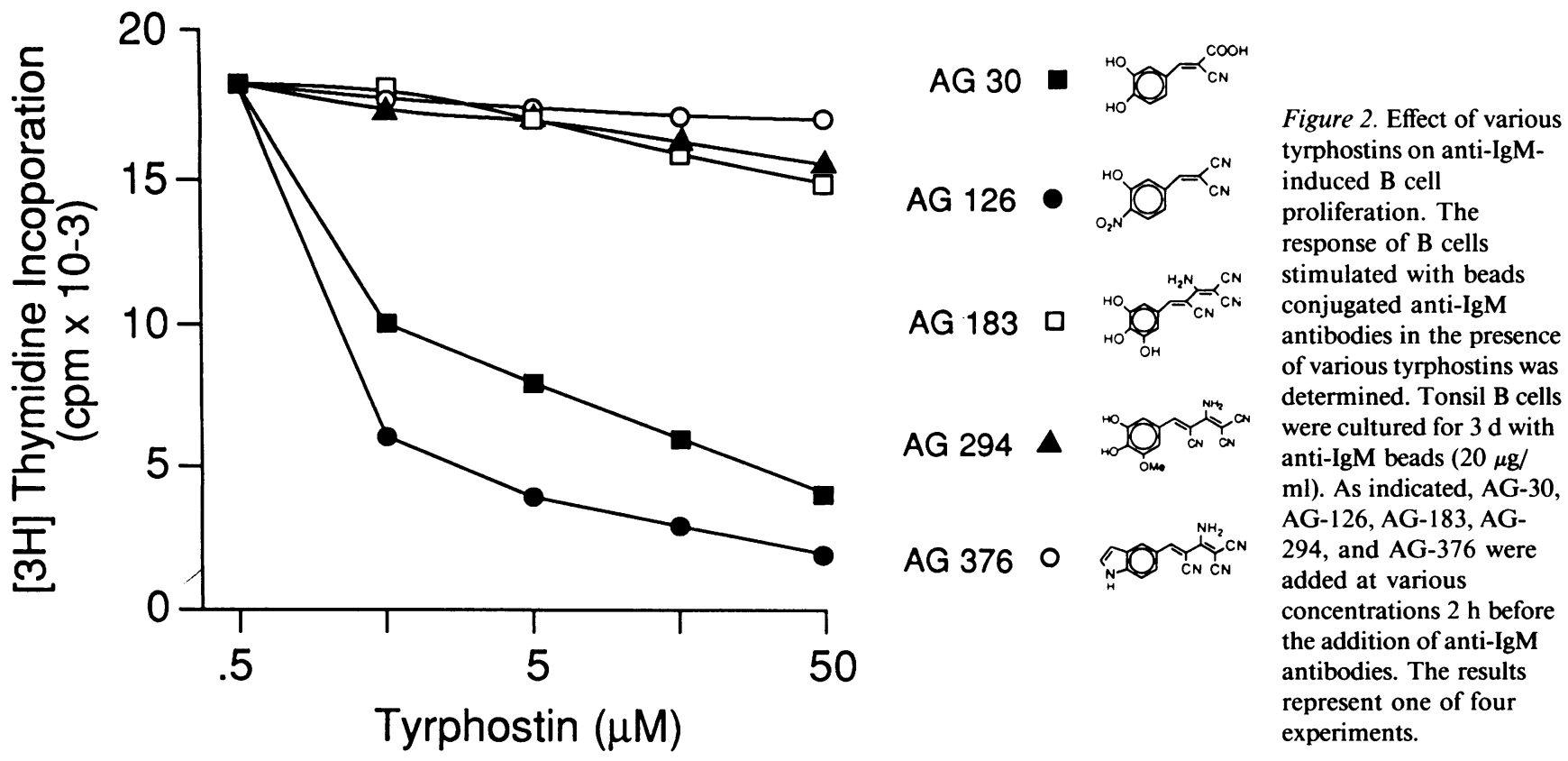


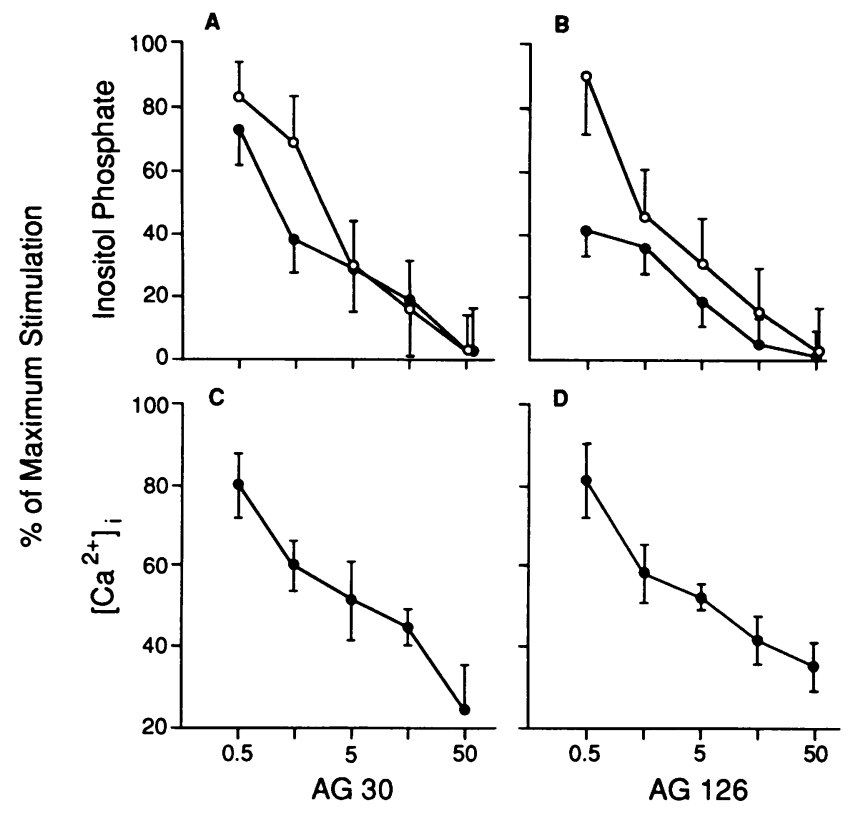

Tyrphostin $(\mu \mathrm{M})$

Figure 3. The effect of tyrphostins on anti-IgM-induced inositol phosphate production and changes in $\left[\mathrm{Ca}^{2+}\right]_{\mathrm{i}}$. (Top) Tonsil B cells were incubated overnight with $\left[{ }^{3} \mathrm{H}\right]$ inositol. Cells were incubated with anti-IgM antibody $(20 \mu \mathrm{g} / \mathrm{ml})$ for $15 \mathrm{~min}$, in the presence or absence of various concentrations of AG-30 $(A)$, or AG-126 $(B)$. Cells were lysed and inositol phosphates separated as described in Methods, and values for $\operatorname{IP}_{3}(\bullet)$ and total IP $(O)$ were determined. Control values (medium alone) were $714 \pm 71 \mathrm{cpm}$ for $\mathrm{IP}_{3}$ and $13,490 \pm 1,450 \mathrm{cpm}$ for total IP $\left(I_{P_{1}}+I_{2}+I P_{3}\right)$. Results represented the mean \pm SD for four replicates pooled from three individual experiments. (Bottom) Cells $\left(2 \times 10^{7}\right)$ were loaded with Indo- 1 by a 30 -min incubation with $2 \mu \mathrm{M}$ of the acetoxymethylester derivative. $1 \times 10^{7}$ cells were preincubated with various concentrations of either AG-30 $(C)$ or AG-126 $(D)$ for $2 \mathrm{~h}$. After extensive washing, cells were added to $\mathrm{Ca}^{2+}$-containing medium. The baseline was determined and $20 \mu \mathrm{g}$ of anti-IgM antibodies added. The values represent the mean $\pm S E M$ increase in $\left[\mathrm{Ca}^{2+}\right]_{\mathrm{i}}$ of six different determinations.

phostins specifically block anti-IgM-induced early events which are proximal to activation of protein kinase $\mathrm{C}$ and increases in $\left[\mathrm{Ca}^{2+}\right]_{i}$ perhaps relating to the inhibition of PLC activity.

To determine if the observed effect of AG-30 and AG-126 resulted from inhibition of PLC itself, we added AG-30 and AG-126 to a PLC enzymatic assay. The production of $\left[{ }^{3} \mathrm{H}\right]$ inositol 1,4,5-trisphosphate from labeled phosphatidylinositol 4,5-bisphosphate by PLC contained in cell lysates was not affected by AG-30 and AG-126 concentrations up to $100 \mu \mathrm{M}$. These results were seen irrespective of whether PLC activity was measured with cytosolic (not presented) or membranebound PLC (Fig. 5). Thus, the inhibitory effect of AG-30 and AG-126 on anti-IgM-induced IP3 and IP production in B cells was not due to direct inhibition of PLC by AG-30 and AG-126.

\section{Discussion}

In this study, we have demonstrated that tyrphostins AG-30 and AG-126 prevent anti-IgM-induced proliferation, oncogene expression, tyrosine phosphorylation, and increases in $\left[\mathrm{Ca}^{2+}\right]_{i}$,

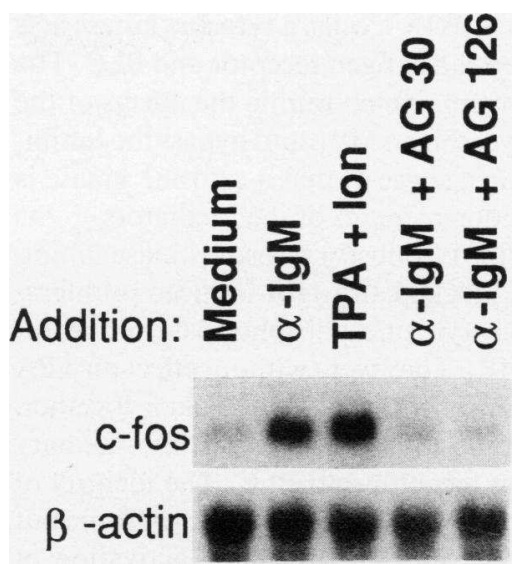

Figure 4. Effect of tyrphostins on levels of $c$ fos and $\beta$-actin RNA after stimulation with anti-IgM antibodies. Tonsil-derived B cells $(3$ $\times 10^{7}$ cells $/ \mathrm{ml}$ ) were incubated with anti-IgM $(20 \mu \mathrm{g} / \mathrm{ml})$ or with TPA $\left(10^{-8} \mathrm{M}\right)$ and ionomy$\operatorname{cin}(1 \mu \mathrm{g} / \mathrm{ml})$ in the presence or absence of AG-30 $(50 \mu \mathrm{M})$ or AG$126(50 \mu \mathrm{M})$. RNA was extracted after $30 \mathrm{~min}$ of incubation and analyzed by Northern Blots as described in Methods. The same blot was probed first with a $c$-fos probe, then stripped and reprobed with the $\beta$-actin probe. Densitometric analysis indicated that in this experiment, treatment with anti-IgM alone resulted in sixfold increase in $c$-fos but no change in $\beta$-actin mRNA levels.

IP, and $\mathrm{IP}_{3}$. In contrast, AG-183, AG-294, and AG-376, in similar concentrations which are effective inhibitors of purified epidermal growth factor receptor tyrosine kinase activity (1416), had little effect on anti-IgM-induced changes in any of these processes. In addition, AG-30 and AG-126 did not alter proliferation induced by TPA and ionomycin, indicating that they did not exhibit significant nonspecific toxicity at the concentrations used.

The ability of the tyrphostins to block anti-IgM-induced increases in $\left[\mathrm{Ca}^{2+}\right]_{i}, \mathrm{IP}$, and $\mathrm{IP}_{3}$ indicates that a tyrosine kinase likely acts as an intermediary between the B cell antigen receptor and PLC. This is further indicated by the lack of a direct effect of AG-30 and AG-126 on the enzymatic activity of PLC. Since PLC $\gamma$ has been demonstrated to be a substrate for the tyrosine kinase activity of both the EGF and PDGF receptors, it is attractive to hypothesize that PLC $\gamma$ is a substrate for the tyrosine kinase activated by the $B$ cell antigen receptor. Antigen-induced tyrosine phosphorylation of a band at $145 \mathrm{kD}$ is consistent with this possibility.

The results reported herein with the tyrphostins are similar to those reported in T cells using genestein (11). However, in contrast to the tyrphostins which inhibit tyrosine phosphorylation by competing for the substrate binding site, genestein and herbimycin compete for the ATP binding site and have a greater potential for nonspecific effects. Nevertheless, the data

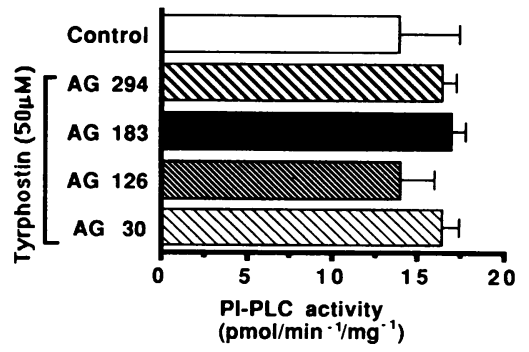

Figure 5. Effects of tyrphostins on membrane-bound PLC in vitro. The enzymatic activity was measured as described in Methods, in the absence or presence of various tyrphostins. Counts from samples incubated with buffer only $(400$

$600 \mathrm{cpm}$ ) were subtracted from all values. The assays' reaction rate was linear with time and amount of protein. Data are mean and range from duplicates of a single experiment. Similar results were obtained in three other experiments. 
suggest that in B cells as well as in T cells, a tyrosine kinase acts as an intermediary between the antigen receptor and PLC. The ability of TPA and ionomycin, which mimic the effects of the products of PLC, diacylglycerol, and $\mathrm{IP}_{3}$, and bypass the inhibitory effect of the tyrphostins, suggests that a tyrosine kinase is located upstream but not downstream of the mediators.

In summary, two specific tyrphostin tyrosine kinase inhibitors, AG-30 and AG-126, blocked anti-IgM-induced proliferation, oncogene expression, tyrosine phosphorylation and increases in $\left[\mathrm{Ca}^{2+}\right]_{i}, I P$, and $\mathrm{IP}_{3}$. They were without effect on TPA and ionomycin-induced $\mathrm{B}$ cell proliferation. Taken together, this indicates that a tyrosine kinase acts as an intermediary between the B cell antigen receptor and PLC. The identity of this kinase remains to be demonstrated. The ability of some but not all tyrphostins to block anti-IgM-mediated activation of PLC may provide an important probe to assist in identifying the kinase. Further, the involvement of tyrosine kinase activity of many oncogene products in the expression of the transformed phenotype identifies these proteins as potential targets for selective chemotherapy and thus, for rational drug design.

\section{Acknowledgments}

This work was supported by grants from the National Cancer Institute of Canada and the Leah Reichmann Research Fund.

\section{References}

1. Cambier, J. C., C. H. Heusser, and M. H. Julius. 1986. Abortive activation of B lymphocytes by monoclonal anti-immunoglobulin antibodies. J. Immunol. 136:3140-3141.

2. Maruyama, S., H. Kubagawa, and M. D. Cooper. 1985. Activation of human B cells and inhibition of their terminal differentiation by monoclonal anti- $\mu$ antibodies. J. Immunol. 135:192-199.

3. Rudich, S. M., R. Winchester, and P. K. A. Mongini. 1985. Human B cell activation. Evidence for diverse signals provided by various monoclonal anti-IgM antibodies. J. Exp. Med. 162:1236-1255.

4. Bijsterbosch, M. K., C. J. Meade, G. A. Turner, and G. G. B. Klaus. 1985. B lymphocyte receptors and polyphosphoinositide degradation. Cell. 41:999-1006.

5. Roifman, C. M., G. B. Mills, D. Stewart, R. K. Cheung, S. Grinstein, and E. W. Gelfand. 1987. Response of human B cells to different anti-immunoglobulin isotypes: absence of correlation between early activation events and cell proliferation. Eur. J. Immunol. 17:1737-1742.

6. Nel, A. E., G. E. Landreth, P. J. Goldschmidt-Clermont, H. E. Tung, and R. M. Galbraith. 1984. Enhanced tyrosine phosphorylation in B lymphocytes upon complexing of membrane immunoglobulin. Biochem. Biophys. Res. Com mun. 125:859-866.

7. Lane, P. J. L., F. M. McConnell, G. L. Schieven, E. A. Clark, and J. A. Ledbetter. 1990. The role of class II molecules in human B cell activation. $J$. Immunol. 144:3684-3692.

8. Gold, M. R., D. A. Law, and A. L. Defranco. 1990. Stimulation of protein tyrosine phosphorylation by the B-lymphocyte antigen receptor. Nature (Lond.) 345:810-813.

9. Campbell, M.-A., and B. M. Sefton. 1990. Protein tyrosine phosphorylation is induced in murine $B$ lymphocytes in response to stimulation with anti-immunoglobulin. EMBO (Eur. Mol. Biol. Organ.) J. 9:2125-2131.

10. Margolis, B., S. G. Rhee, S. Felder, M. Mervic, R. Lyall, A. Levitzki, A. Ullrich, A. Zilberstein, and J. Schlessinger. 1989. EGF induces tyrosine phosphorylation of phospholipase C-11: a potential mechanism for EGF receptor signaling. Cell. 57:1101-1107.

11. Mustelin, T., K. M. Coggeshall, N. Isakov, and A. Altaman. 1990. T cell antigen receptor-mediated activation of phospholipase $\mathrm{C}$ requires tyrosine phosphorylation. Science (Wash. DC). 247:1584-1587.

12. Akiyama, T., J. Ishida, S. Nakagawa, H. Ogawara, S.-I. Watanabe, N. Itoh M. Shibuya, and Y. Fukani. 1987. Genistein, a specific inhibitor of tyrosine-specific protein kinases. J. Biol. Chem. 262:5592-5595.

13. Graziani, Y., E. Erikson, and R. L. Erikson. 1983. The effect of quercetin on the phosphorylation activity of the Rous sarcoma virus transforming gene product in vitro and in vivo. Eur. J. Biochem. 135:583-589.

14. Gazit, A., P. Yaish, C. Gilon, and A. Levitzki. 1989. Tyrophostins I: synthesis and biological activity of protein tyrosine kinase inhibitors. J. Med. Chem. 32:2344-2352.

15. Yaish, P., A. Gazit, C. Gilon, and A. Levitzki. 1988. Blocking of EGF-dependent cell proliferation by EGF receptor kinase inhibitors. Science (Wash. DC). 242:933-938.

16. Shechter, Y., P. Yaish, M. Chorev, C. Gilon, S. Braun, and A. Levitzki. 1989. Inhibition of insulin-dependent lipogenesis and anti-lipolysis by protein tyrosine kinase inhibitors. EMBO (Eur. Mol. Biol. Organ.) J. 8:1671-1676.

17. Splawski, J. B., and P. Lipsky. 1987. Antigen induced proliferation and immunoglobulin A secretion by a human-human hybridoma. J. Immunol. 139:1432-1437.

18. Mills, G. B., C. May, M. McGill, M. Fung, M. Baker, R. Sutherland, and W. C. Greene. 1990. Interleukin 2 induced tyrosine phosphorylation: IL2RB is tyrosine phosphorylated. J. Biol. Chem. 265:3561-3567.

19. Jackowski, S., C. V. Rettenmier, C. J. Sherr, and C. O. Rock. 1986. A guanine nucleotide-dependent phosphatidylinositol 4,5-disphosphate phospholipase $\mathrm{C}$ in cells transformed by the v-fms and v-fes oncogenes. J. Biol. Chem 261:4978-4985.

20. Chomczynski, P., and N. Sacchi. 1987. Single-step method of RNA isolation by acid guanidinium thiocyanate-phenol chloroform extraction. Anal. Biol. Chem. 162:156-159.

21. Roifman, C. M., D. Hummel, H. Martinez-Valdez, P. Thorner, P. J. Doherty, S. Pan, and A. Cohen. 1989. Depletion of $\mathrm{CD}^{+}$cells in human thymic medulla results in selective immune deficiency. J. Exp. Med. 170:2177-2182.

22. Greenberg, M. E., and E. B. Ziff. 1984. Stimulation of 3T3 cells induces transcription of the c-fos proto-oncogene. Nature (Lond.). 311:433-438.

23. Kruijer, W., J. A. Cooper, T. Hunter, and I. Verma. 1984. Platelet-derived growth factor induces rapid but transient expression of the $\mathrm{c}$-fos gene and protein. Nature (Lond.). 312:711-716.

24. Roifman, C. M., S. H. Benedict, R. K. Cheung, and E. W. Gelfand. 1987. Induction of human B cell proliferation and differentiation by the combination of phorbol ester and ionomycin. Eur. J. Immunol. 17:701-706. 